International Journal of Engineering \& Technology, $7(2.29)(2018) 56-59$
International Journal of Engineering \& Technology
SPC
Website: www.sciencepubco.com/index.php/IJET
Research paper

\title{
Nitrate contamination in groundwater agricultural of Samno and Elzegan area, Fazan region, Libya
}

\author{
Mabroka Mohamed Daw ${ }^{1}$, Elhadi Ramadan Ali $^{2}$, Mohd Ekhwan Toriman ${ }^{3}$ \\ ${ }^{1,2,3}$ School of Social, Development \& Environmental Studies, FSSK, University Kebangsaan Malaysia, 43600. \\ Bangi Selangor MALAYSIA \\ *Corresponding author E-mail: mabrokadaw@gmail.com
}

\begin{abstract}
This paper study explores the groundwater nitrate pollution associated with agricultural activities in Samno and Elzegan areas, Libya. The study's main aim is to evaluate the condition of groundwater agricultural in the study area. 40 water samples were collected from forty established wells used of daily domestic and public utilities from first of January to end of July 2014 the samples were collected subjected from different aquifer levels and depths. The water samples' NO3 concentration was measured using the hackspectrophotometer nitrate test. The findings revealed that a major portion of the groundwater samples had a significant NO3 concentration; only $12.5 \%$ wells were recorded at the saver level. Meanwhile, $87 \%$ wells were recorded as polluted with NO3, $27.5 \%$ wells were in severing level and $60 \%$ wells were recorded as slightly to moderate levels. The main sources of NO3 in the groundwater come from an excessive use of chemical fertilizers and pesticides. This study recommends that most of the wells operated within the study areas are not suitable for any household or agricultural purposes.
\end{abstract}

Keywords: Groundwater Agricultural; contamination; nitrate; Libya

\section{Introduction}

Nitrate is the highest form of oxidized nitrogen compound and it is widely available in the surface water and groundwater since it is the final component of aerobic decomposition in the organic nitrogenous matter (Cepuder \& Shukla 2002). Groundwater nitrate contamination is quite common in many areas globally. Among the main contamination problems is the issue of pollution of groundwater from point and non-point sources. Some of the sources of contamination of nitrate are such as localized waste water, land fertilizers, sewerage systems, agricultural pesticides and fertilizers, industrial effluents, human waste lagoons, animal feedlots, geological sources, as well as natural soil organic matter (Bartram \& Ballance 1996). Nitrate is extremely water soluble making it moves freely in the soil solution. Moreover, the transformation of nitrogen is the soil is dynamic as well as complex. It is possible to develop large amount of $\mathrm{N}$ losses through the volatilization of ammonia, leaching, surface run-off, and denitrification (Mustafa \& Ahmad 2008)The main source of drinking water in the areas of Samno and Elzegan comes from the groundwater. When the content of nitrate exceeds $10 \mathrm{mg} \mathrm{NO} 3 / 1$ liter of drinking water, it could become toxic to babies and has the potential to in crease stomach cancer in adults (Spalding \& Exner, 1993). The main health risk linked to exposure to nitrates for humans is known as methemoglobinemia, which transforms hemoglobin to methemoglobin. This would lead to low methemoglobin concentrations $(0.5 \%-3 \%)$ in an average person; however, a person could have concentrations of about $10 \%$ without showing any clinical symptoms.

A person with a methemoglobin concentration of more than $10 \%$ could contract cyanosis, which is symbolized by bluish lips and skin while anyone with a concentration of more than $25 \%$ could suffer from rapid pulse rates, hypotension, and rapid breathing rates (Omed M. Mustafa \& Hiwa S. Ahmad 2008). According to Pacheco et al. (2001), while boiling water kills many bacteria, it causes the nitrate ions to concentrate in the water. As many people tend to boil water to make milk for babies, this could lead to serious consequences and should be avoided (Trojan et al. 2003). The nitrate ions move effortlessly in the soil transported by rainwater or irrigation water into the supply of groundwater. In this case, wells that utilize the groundwater could be severely impacted. Wells that are shallow, not properly built or maintained, or those that are dug in sandy soil could potentially be contaminated by nitrate. Nitrate's acceptable maximum concentration for drinking water as set by the World Health Organization is $50 \mathrm{ppm} \mathrm{NO} 3$, which is equivalent to $11.3 \mathrm{ppm} \mathrm{NO3-N}$ (WHO, 2006). In Libya, the Drinking Water Quality Standard is $40 \mathrm{ppm}$ and in Canada (Canada, 2006), it is 45 ppm NO3 ( 10 ppm NO3 -N). Nitrate concentrations in groundwater are typically less than $10 \mathrm{ppm}$, but can exceed that in areas of concentrated human sources. Empirical research shows that over time, the level of nitrate in groundwater has been slowly increasing and this trend will continue unless a major change is carried out in the practices of local land usage (Trojanet al., 2003). It has been found that in locations where there is high human activity, the concentration of nitrate is higher compared to more remote locations (Benson et al., 2007).

\section{Location}

Samno and Elzegan areas are located in the Elbawaniss area in the Fazan region, which is located in the southeast of Libya between the latitude of $26^{\circ} 40^{\prime}-27^{\circ} 45^{\prime} \mathrm{N}$ and the two longitudes of $14^{\circ} 30^{\prime}$ and $16^{\circ} 00^{\prime} \mathrm{E}$, covering an area of $9557 \mathrm{~km}$ square (Figure1) (Alghariani 2006) 


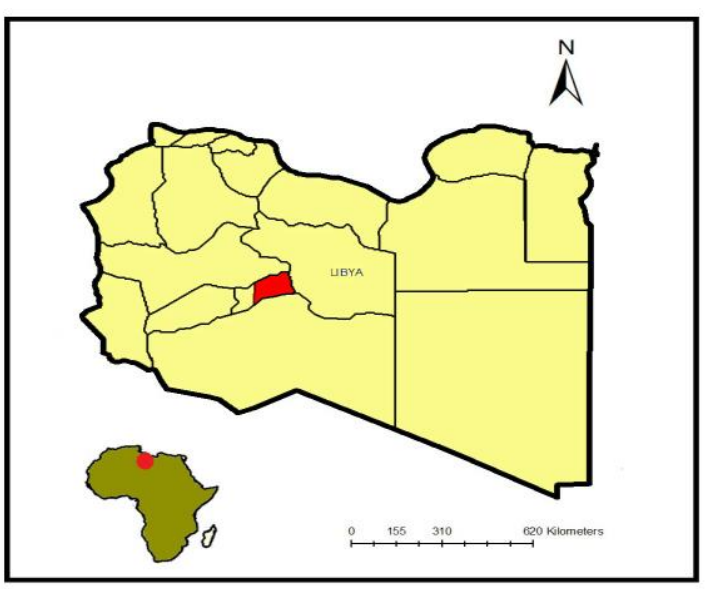

Fig. 1: Location map of the studied area

\section{Climate}

The climate in the studied area is classified as the Sahara climate, showing seasonal variations between very hot and dry in summer, and very cold in winter. Rain is rare in this region. The temperature of the air in terms of annual mean is $40^{\circ} \mathrm{C}$ in July and $50^{\circ} \mathrm{C}$ in January; the mean annual evaporation is $15.8 \mathrm{~mm}$ and the mean annual rainfall is $0.5 \mathrm{~mm} 3$ (Ageena 2013)

\section{Hydrogeology}

All groundwater samples are collected from wells that belong to the Murzuk basin, which is located in the Fazan region in the south of Libya. All these areas depend on this groundwater. Figure (2) shows the location of the study area in the Murzuk basin. Shallow Quaternary aquifer with $25-57 \mathrm{~m}$ depth represents a good and widespread aquifer in the study area. The aquifer is composed of unconsolidated gravel, sand, silt, and clay that yield a good quantity of water. The Murzuk basin is divided into two main parts; the first one is called the old period reservoir and the second one is called the medium period reservoir. The study area of Formation aquifer represents medium to deep aquifer $(25-120 \mathrm{~m})$ composing of alternation of marly limestone, sandstone, marl, and occasionally, the conglomerate bed. The study area depends on the second part of the Murzuk basin (the medium period reservoir) in the agricultural (Water \& Jamahiriya 2001)

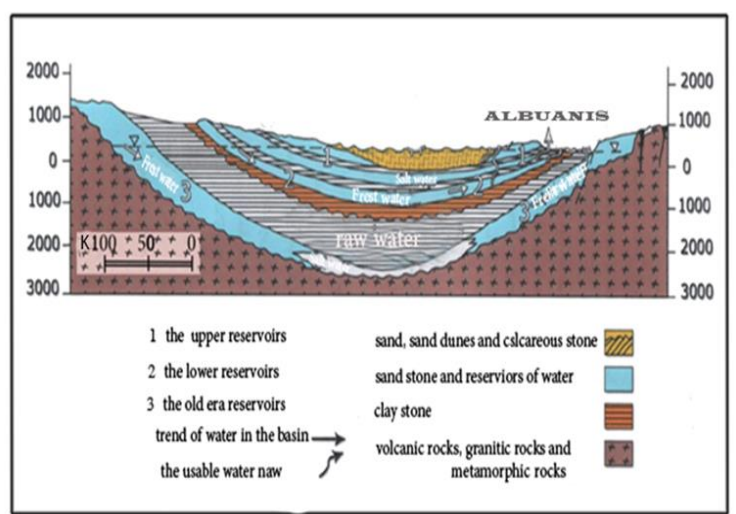

Fig. 2: Hydrological map of the studied area (modified from the author, 2014)

\section{Geology of the area}

Libya comprises part of the Sahara Desert, and contrary to general opinion, only 16 to 20 percent of the country is covered by sanddune areas, notably the Ubari and the Murzuk Sand Seas in Fezzan, and the Calanscio and the Rebiana Sand Seas in central Cyrenaica.
A greater part of the Libyan Desert is occupied by the hamadas (rocky plains) and the sarirs (gravel plains). This part of the Libyan Desert is one of the most fascinating areas for the study of the desert and its morphology.

Climatically, deserts have been described as regions where evaporation exceeds precipitation, or in relation to their vegetative aspects, as places where pre-maintain a continuous capitation is too meager for plant cover. The inadequacy of precipitation in the Libyan Sahara may be due to the fact that the Sahara is a tradewind desert. The constant Trades are not normally evaporating winds because they become progressively warmer as they descend from higher to lower altitudes and proceed from higher to lower latitudes. However, the occasional desert rainfall is of great geomorphic importance. The desert rain occurs in torrential downpour over restricted areas even though no rain may fall in many areas for years. The surfaces of the rocks are subject to great extremes of temperature, as previously mentioned. It appears that the processes of heating, cooling, and slow chemical alteration are each in part responsible for the granular disintegration and exfoliated peeling, which provides the characteristic aspect of desert weathering. Lack of plant cover results in continuous exposure, therefore, as a result of chemical decomposition by occasional rains, high temperature variation, and constant exposure, granular disintegration and accumulation of waste are made possible. These grains in turn break down to produce fine sand, which accumulates around the detached boulders and at the base of the hills. (Goudarzi \& Pecoran.d.)

\section{Materials and methods}

Within the Samno and Elzegan areas, 40 wells (domestic and public) were sampled from 1 January to the end of July 2014. Sampling sites were selected by random sampling including most parts of the Samno and Elzegan areas (see Figure 3). Polyethylene bottles with 1.5 liter capacity that were pre-cleaned were utilized for sample collection. The parameters of concentration of hydrogen ions $(\mathrm{pH})$, conductivity of electricity $(\mathrm{Ec})$, total of dissolved solids (TDS), total of hardness (TH), and nitrate (NO) were analyzed (Table 1) for each sample in 3 laboratories in the Environmental Faculty in the Elshatti area, which belongs to the University of Sabha (Table 2).

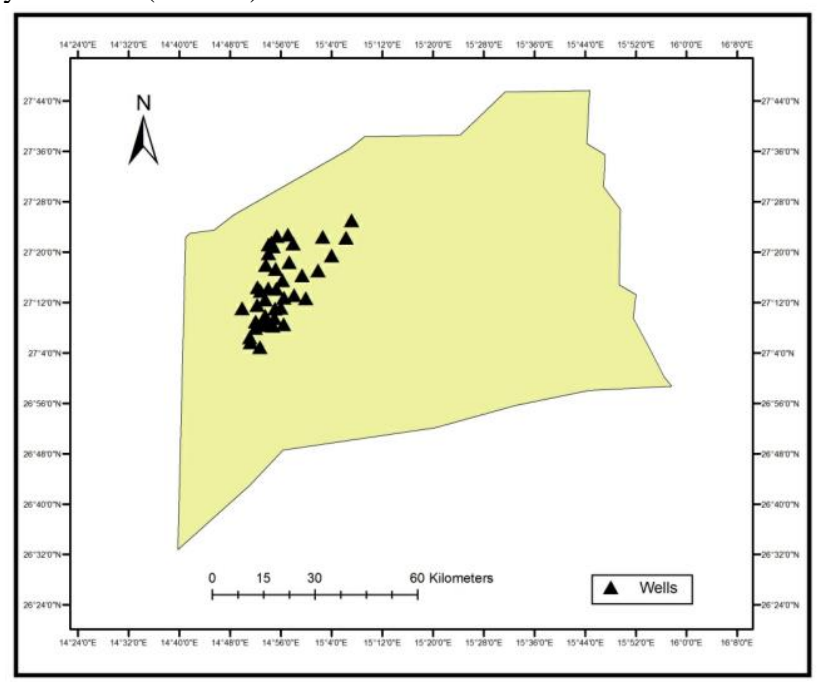

Fig. 3:Distribution of the sample wells in the study area.

\section{Results}

Concentration of NO3, TDS, TH, pH, and Ec are shown in Table 1. Hydrogen ion concentration ranges between $6.02-6.09$, which means all the samples are weak in acidic content. Electrical conductivity ranges between $741-1150 \mathrm{~S} / \mathrm{cm}$ with a higher value of 1150 in W-6 and W-37. Total dissolved salts show a wide variation (519.39-768.56 Mg/L), displaying higher values in all the 
wells in the study area. Total hardness ranges between $118-293$ $\mathrm{Mg} / \mathrm{L}$ with maximum value in $\mathrm{W}-28$ and minimum value in $\mathrm{W}-2$. Nitrate NO3 concentration in the analyzed samples shows a wide range and varies from $4.4 \mathrm{Mg} / \mathrm{L}$ in $\mathrm{W}-1, \mathrm{~W}-13$, and $\mathrm{W}-30$ to a maximum of $122 \mathrm{Mg} / \mathrm{L}$ in $\mathrm{W}-33,150 \mathrm{Mg} / \mathrm{L}$ in $\mathrm{W}-26$, and 176 $\mathrm{Mg} / \mathrm{L}$ in W-8. Generally, higher NO3 values appear in the Elzegan area wells.

Table 1: Analyzed parameters of water samples

\begin{tabular}{|c|c|c|c|c|c|c|}
\hline sample NO & Depth (m) & $\mathrm{pH}$ & Ec & TDS & TH & NO3 \\
\hline W-1 & 104 & 6.7 & 780 & 526.66 & 144 & 4.4 \\
\hline W-2 & 111 & 6.5 & 889 & 577.98 & 118 & 13 \\
\hline W-3 & 85 & 6.6 & 1000 & 645.76 & 129 & 22 \\
\hline W-4 & 250 & 6.1 & 1100 & 623.12 & 271 & 17 \\
\hline W-5 & 96 & 6.8 & 1015 & 698.54 & 219 & 30 \\
\hline W-6 & 110 & 6.4 & 1150 & 534.87 & 216 & 33 \\
\hline $\mathrm{W}-7$ & 101.18 & 6.6 & 1015 & 528.65 & 244 & 26 \\
\hline W-8 & 114.86 & 6.9 & 1007 & 766.66 & 182 & 176 \\
\hline W-9 & 113 & 6.6 & 756 & 765.32 & 142 & 35 \\
\hline $\mathrm{W}-10$ & 80 & 6.3 & 854 & 634.98 & 239 & 29 \\
\hline $\mathrm{W}-11$ & 110 & 6.9 & 943 & 723.76 & 162 & 26 \\
\hline W-12 & 250 & 6.4 & 923 & 598.32 & 274 & 8.8 \\
\hline $\mathrm{W}-13$ & 106 & 6.8 & 765 & 732.43 & 175 & 4.4 \\
\hline W-14 & 112 & 6.3 & 1014 & 643.78 & 128 & 17 \\
\hline $\mathrm{W}-15$ & 217 & 6.6 & 1178 & 744.76 & 139 & 4.4 \\
\hline W-16 & 83 & 6.9 & 958 & 599.45 & 145 & 6.6 \\
\hline $\mathrm{W}-17$ & 102 & 6.5 & 1119 & 633.98 & 251 & 35 \\
\hline W-18 & 219 & 6.4 & 879 & 623.49 & 239 & 24 \\
\hline W-19 & 292 & 6.9 & 912 & 768.56 & 238 & 29 \\
\hline W-20 & 120 & 6.2 & 1118 & 746.23 & 129 & 35 \\
\hline W-21 & 270 & 6.6 & 1000 & 645.65 & 137 & 33 \\
\hline W-22 & 140 & 6.5 & 1054 & 587.55 & 140 & 21 \\
\hline $\mathrm{W}-23$ & 134 & 6.4 & 945 & 598.21 & 230 & 4.4 \\
\hline W-24 & 119 & 6.9 & 800 & 675.32 & 249 & 8.8 \\
\hline $\mathrm{W}-25$ & 120.19 & 6.1 & 1118 & 733.67 & 130 & 24 \\
\hline W-26 & 130 & 6.8 & 1019 & 721.76 & 127 & 150 \\
\hline W-27 & 300 & 6.5 & 888 & 693.36 & 231 & 24 \\
\hline W-28 & 210 & 6.8 & 1099 & 627.81 & 293 & 32 \\
\hline W-29 & 279 & 6.3 & 912 & 519.39 & 200 & 18 \\
\hline W-30 & 135 & 6.9 & 741 & 759.34 & 124 & 4.4 \\
\hline W-31 & 110 & 6.7 & 890 & 643.28 & 283 & 16 \\
\hline W-32 & 99 & 6.4 & 1011 & 598.26 & 245 & \\
\hline W-33 & 125 & 6.9 & 1002 & 692.17 & 126 & \\
\hline W-34 & 118 & 6.2 & 967 & 629.36 & 148 & \\
\hline W-35 & 86 & 6.5 & 854 & 766.66 & 268 & \\
\hline W-36 & 256 & 6.8 & 1090 & 700 & 186 & \\
\hline W-37 & 110 & 6.7 & 1150 & 577.34 & 184 & \\
\hline W-38 & 120 & 6.6 & 1016 & 729.16 & 244 & \\
\hline W-39 & 116 & 6.9 & 798 & 645.87 & 282 & \\
\hline W-40 & 278 & 6.5 & 800 & 716 & 199 & \\
\hline
\end{tabular}

Ec in $\mathrm{uS} / \mathrm{cm}$; TDS, TH, and NO3 in Mg/L; Depth in $\mathrm{m}$

Table 2: Procedures, techniques and methods used in sample analysis

\begin{tabular}{|c|c|c|}
\hline Test & Method & Instrument \\
\hline NO & $\begin{array}{c}\text { Ultravio- } \\
\text { let screening }\end{array}$ & $\begin{array}{c}\text { Spectrophotome- } \\
\text { ter 220nm/ CECIL/ 2021 }\end{array}$ \\
\hline $\mathrm{pH}$ & Probe method & $\begin{array}{c}\text { Portable multipara- } \\
\text { meter/ Field Lab Analyzer }\end{array}$ \\
\hline Ec & Probe method & $\begin{array}{c}\text { Portable multipara- } \\
\text { meter/ Field Lab Analyzer }\end{array}$ \\
\hline TDS & Drying & Beaker, filter paper, oven \\
\hline TH & EDTA titrimetric & Erlenmeyer flask, burette \\
\hline
\end{tabular}

\section{Discussion}

Essentially, NO3 values in the collected samples from the studied area are high. Evaluation and assessment of nitrate pollution is displayed as higher, slight to moderate, and not polluted as follows:

The higher level or the maximum contamination level (MCL) represented in the eleven wells are shown in Table 1. Water from the mentioned wells is polluted with NO3, which exceeds the maximum contamination level (MCL) and the values are $32 \mathrm{Mg} / \mathrm{L}$ in $\mathrm{W}-28,33 \mathrm{Mg} / \mathrm{L}$ in $\mathrm{W}-6$ and $\mathrm{W}-21,35 \mathrm{Mg} / \mathrm{L}$ in $\mathrm{W}-9, \mathrm{~W}-17, \mathrm{~W}-20$, and $\mathrm{W}-38,122 \mathrm{Mg} / \mathrm{L}$ in $\mathrm{W}-33,150 \mathrm{Mg} / \mathrm{L}$ in $\mathrm{W}-26$ and $176 \mathrm{Mg} / \mathrm{L}$ in $\mathrm{W}-8$; FAO (2005) recommendations are as follows: < 5 none, 5-30 slight to moderate, and > 30 severe;

The lowest level or not polluted wells represent five wells as shown in Table 1; five samples are not polluted with NO3 and do not exceed the MCL. These wells are W-1, W-13, $\mathrm{W}-15, \mathrm{~W}-23$, and $\mathrm{W}-30$ with a value of $4.4 \mathrm{Mg} / \mathrm{L}$; and

The moderate level of 5-30 is represented in 24 samples collected from wells in the study area (Table 1); the lowest value in this group is $6.6 \mathrm{Mg} / \mathrm{L}$ in $\mathrm{W}-16$ and $\mathrm{W}-34$, while the highest value is $30 \mathrm{Mg} / \mathrm{L}$ in W-5 and W-37.

Generally, thirty-five wells show pollution with NO3, which represent $87.5 \%$ of the groundwater in the Samno and Elzegan areas. The main source of NO3 in the groundwater of Samno and Elzegan areas is from the use of chemical fertilizers and pesticides. The NO3 Pollution is distributed in the whole study area along different aquifers (Samno and Elzegan) and at different depths (Table 1) but the most infected wells are W-8, W-26, and W-33 (Figure 4). The contaminant (NO3) from the use of chemical fertilizers and pesticides may be transported within the intergranular Quaternary aquifer, and at depths along the vertical and horizontal fissures and micro fractures. Poorly constructed wells may also account for the vertical transport (Cronin et al., 2003) and leaky wells can rapidly transmit contaminants from the surface through low permeability strata into the otherwise uncontaminated aquifers (Lacombe et al., 1995). To resolve the NO3 pollution problem in the groundwater in Samno and Elzegan, it is proposed that the utilization of chemical pesticides and fertilizers is reduced and alternatives that may cause less damage are found, such as pumping methanol into the aquifer to reduce the nitrate (pentavalent nitrogen) to zero gas nitrogen, and the latter can be degassed leading to a decrease of nitrate concentrates.

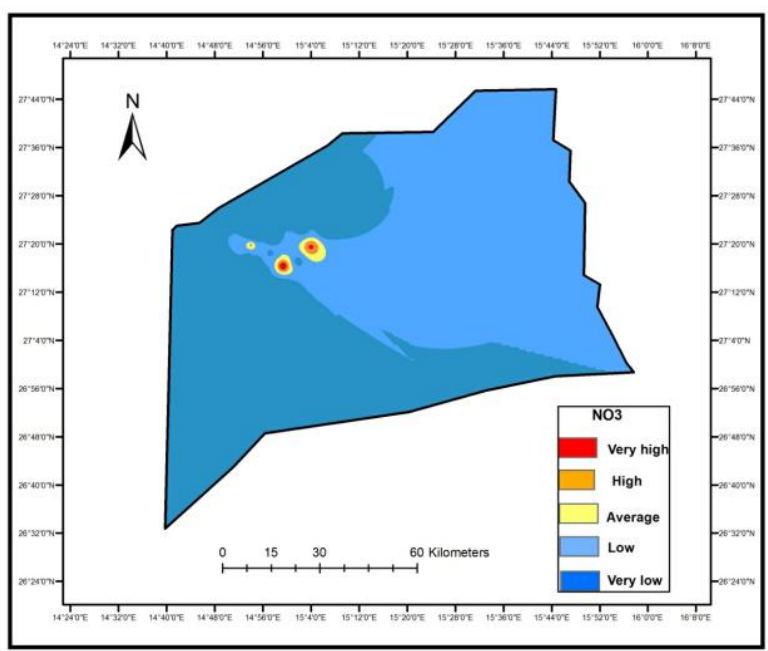

Fig. 4: Distribution of nitrate in the groundwater in the study area.

\section{Conclusions}

Concentrations of nitrate in the groundwater of the Samno and Elzegan areas are high, and (NO3) values in majority of the wells exceed the maximum contamination level of MCL. The majority of drilled wells (35 wells) are polluted with (NO3), also the most of the water samples are polluted with NO3 while others shows a high concentration. About $87.5 \%$ of the groundwater in Samno and Elzegan shows pollution with (NO3). The main source of groundwater pollution by $\mathrm{NO} 3$ is the use of chemical fertilizers and pesticides in the same time the contaminant of NO3 transports to depth perpendicularly and/ or horizontally within the intergranular, fissured, and fractured aquifers of the Quaternary sediments, respectively; and water from polluted and highly contaminated 
wells is not suitable for household and agricultural purposes in the Samno and Elzegan areas.

\section{References}

[1]. Ageena, I.M., 2013. Trends and patterns in the climate of Libya Thesis submitted in accordance with the requirements of the University of Liverpool for the degree of Doctor of Philosophy. , (November).

[2]. Alghariani, S.A., 2006. Reducing Agricultural Water Demand in Libya Through the Improvement of Water Use Efficiency and Crop Water Productivity. , 2025, pp.99-107.

[3]. Bartram, J. \& Ballance, R., 1996. Water quality monitoring: a practical guide to the design and implementation of freshwater quality studies and monitoring programmes, Available at: http://trafficlight.bitdefender.com/info?url=https\%3A//books.googl e.com/books\%3Fh1\%3Den\%261r\%3Dlang_en\%26id\%3DwFijb1Iv CIC\%26oi\%3Dfnd\%26pg\%3DPR11\%26dq\%3DBartram+and+Ball ance $\% 2 \mathrm{C}+1996 \% 26$ ots\%3D5nDPMINHo8\%26sig\%3DX85_fXDb ne3BT91BKwLCZ34CsmI\&language=en_US [Accessed July 11, 2016].

[4]. Cepuder, P. \& Shukla, M., 2002. Groundwater nitrate in Austria: a case study in Tullnerfeld. Nutrient Cycling in Agroecosystems. Available

http://trafficlight.bitdefender.com/info?url=http\%3A//link.springer. com/article/10.1023/A\%3A1021438310211\&language=en_US [Accessed July 11, 2016].

[5]. Goudarzi, G.H. \& Pecora, W.T., Geology and Mineral Resources of Libya- A Reconnaissance.

[6]. Mustafa, O. \& Ahmad, H., 2008. Nitrate Pollution in Groundwater of Sulaimaniyah City, Kurdistan Region, NE Iraq. Iraqi Bulle-tin of Geology and Mining. Available at: http://trafficlight.bitdefender.com/info?url=http\%3A//www.academ ia.edu/download/31577636/Nitrate_Pollution_in_Groundwater_of_ Sulaimani_City_Kurdistan_Region.pdf\&language=en_US [Accessed July 11, 2016].

[7]. Trojan, M. et al., 2003. Effects of land use on ground water quality in the Anoka Sand Plain Aquifer of Minnesota. Ground. Available at:

http://trafficlight.bitdefender.com/info?url=http $\% 3 \mathrm{~A} / /$ onlinelibrary. wiley.com/doi/10.1111/j.1745-

6584.2003.tb02382.x/full\&language=en_US [Accessed July 11 2016].

[8]. Water, G. \& Jamahiriya, A., 2001. Regional Aquifer Systems. , (42), pp.20-24. 